\title{
Variables involved in the perception of psychological harassment in the nursing work environment ${ }^{1}$
}

\author{
Kátia Biagio Fontes² \\ Maria Dalva de Barros Carvalho ${ }^{3}$
}

\begin{abstract}
This is a descriptive-exploratory study with a quantitative approach, with the objective of identifying how nurses perceive psychological harassment at work, the behaviors experienced and the variables involved. In collecting data, two questionnaires were used: one socio-professional and another for identifying the behaviors involving psychological harassment experienced by the subjects in the previous twelve months, along with the duration and frequency of the behaviors. At the end of the questionnaire, a dichotomous question was added, which addressed nurses' perceptions in relation to feeling victimized by psychological harassment at work. Both the questionnaires were applied in electronic and print format between May and September 2010. The data was analyzed through descriptive statistics. The results showed that some of the subjects felt that they were victims of psychological harassment. Only the variables related to characterization of the psychological harassment presented significant association. The following were highlighted among the most-referred-to behaviors: "They question your decisions" and "You receive verbal attacks criticizing work you have done". It's important to open spaces for discussing violence at work, so that managers may establish strategic measures for preventing and containing this type of violence, so as to ensure health, dignity and well-being at work. It is also important to discuss this issue in the academic space, so as to give the theme greater visibility, such that future nurses will be able to identify and appropriately confront this type of violence.
\end{abstract}

Descriptors: Nursing; Violence; Working Environment; Bullying; Occupational Health.

\footnotetext{
${ }^{1}$ Paper extracted from Master's Thesis "Do invisível ao visível: assédio moral e o trabalho do enfermeiro", presented to Universidade Estadual de Maringá, Brazil.

2 MSc, Profesor, Universidade Paranaense, Brazil.

${ }^{3}$ PhD, Profesor, Universidade Estadual de Maringá, Brazil.
}

Corresponding Author:

Kátia Biagio Fontes

Universidade Paranaense. Curso de Enfermagem. Instituto de Ciências

Biológicas, Médicas e da Saúde

Praça Mascarenhas de Moraes, 4282

Zona III

CEP: 87502-210, Umuarama, SP, Brasil

E-mail: katia.bf@gmail.com 


\section{Variáveis envolvidas na percepção do assédio moral no ambiente laboral da Enfermagem}

Trata-se de estudo descritivo-exploratório, de abordagem quantitativa, com o objetivo de identificar a percepção de enfermeiros sobre o assédio moral no trabalho, condutas vivenciadas e variáveis envolvidas. Na coleta de dados, utilizaram-se dois questionários: um socioprofissiográfico e outro para identificar as condutas de assédio moral, vivenciadas pelos sujeitos nos últimos 12 meses, o período e a frequência das condutas. Ao final do questionário, foi adicionada uma questão dicotômica que abordava a percepção do enfermeiro em relação a se sentir vítima de assédio moral no trabalho. Ambos os questionários foram aplicados no formato eletrônico e impresso, entre maio e setembro de 2010. Os dados foram tratados por estatística descritiva. Os resultados mostraram que parte dos sujeitos sentiu-se vítima de assédio moral. Somente as variáveis relacionadas à caracterização do assédio moral apresentaram associação significativa. Entre as condutas mais referidas, destacaram-se: "questionam as decisões que você toma" e "você recebe ataques verbais criticando trabalhos realizados". É importante a abertura de espaços para discussão sobre a violência no trabalho, para que gestores possam estabelecer medidas estratégicas de prevenção e contenção desse tipo de violência, a fim de garantir a saúde, a dignidade e o bem-estar no trabalho. Torna-se importante, também, discutir o assunto no espaço acadêmico, a fim de dar maior visibilidade ao tema, para que futuros enfermeiros possam identificar e enfrentar adequadamente esse tipo de violência.

Descritores: Enfermagem; Violência; Ambiente de Trabalho; Bullying; Saúde do Trabalhador.

\section{Variables relacionadas con la percepción del asedio moral en el ambiente laboral de la enfermería}

Estudio descriptivo-exploratorio de abordaje cuantitativo, con el objetivo de identificar la percepción de enfermeros sobre el asedio moral en el trabajo, las conductas vividas y las variables relacionadas. En la recogida de datos se utilizó un cuestionario socio-profesiográfico y otro para identificar las conductas de asedio moral vividas por los sujetos en los últimos doce meses, el periodo y la frecuencia de las conductas. Al final del cuestionario fue adicionada una cuestión dicotómica relacionada a la percepción del enfermero cuanto a sentirse víctima de asedio moral en el trabajo. Los dos cuestionarios fueran aplicados electrónicamente e impresos entre mayo y septiembre de 2010. Los datos fueran tratados por estadística descriptiva. Los resultados mostraron que los sujetos se sintieron víctimas de asedio moral. Solamente las variables relacionadas a la caracterización del asedio moral presentaron asociación significativa. Entre las conductas más referidas, se destacaron: "Cuestionan las decisiones que usted toma" y "Usted recibe ataques verbales criticando trabajos realizados". Es importante la apertura de espacios de discusión sobre la violencia en el trabajo para que gestores puedan establecer medidas estratégicas de prevención y contención de este tipo de violencia a fin de garantizar la salud, la dignidad y el bienestar del profesional en el trabajo. También es importante discutir el tema en el ámbito académico, con el fin de dar mayor visibilidad a la cuestión, para que los futuras enfermeros puedan identificar y abordar adecuadamente este tipo de violencia.

Descriptores: Enfermería; Violencia; Ambiente de Trabajo; Intimidación; Salud Laboral.

\section{Introduction}

The term mobbing was first used in the occupational environment by Leymann, to refer to a type of workplace violence which was not physical, but rather psychological, and characterized by highly sophisticated behaviors. Leymann defines it as hostile communication which is devoid of ethics, administered in a systematic form by one or a few individuals against a single individual who, as a consequence of this, is subjected to a prolonged situation of solitude and exposure to frequent and persistent attacks over a prolonged period(1). Since then, various scholars have expounded their theories on psychological harassment in this context ${ }^{(2-3)}$. However, there is still no agreement on the definition of psychological harassment. 
It is not related to demanding management, but, as a perverse form of management which has been tolerated(4) it is capable of generating negative consequences for quality of life at work and - in extreme cases - for workers' health, signifying losses to the organization and to society(5).

Various scholars have emphasized psychological violence experienced by nurses in the work environment(6-7) and their vulnerability in the face of psychological harassment. Nurses suffering harassment present reduction in their motivation for work, in their ability to concentrate, in their productivity, in their commitment to their job, and in the quality of their relationship with patients, colleagues and managers ${ }^{(8)}$. At the same time they present increased anxiety, depression, propensity to quit their job and symptoms of burnout ${ }^{(9)}$.

Researchers aiming to identify psychological harassment - specifically in the nursing work environment - have used different instruments for identifying nurses suffering harassment. This being so, some studies have used as a reference the parameters of duration and frequency of exposure to attacks established by Leymann. According to Leymann's criteria, for an individual to be identified as a victim of psychological harassment, he or she must have suffered at least one attack per week over a minimum period of six months ${ }^{(1)}$. However, the seriousness of the psychological harassment does not depend only on its duration, as some hostile attitudes can destroy a person in less than six months ${ }^{(3)}$.

A study carried out in Spain, with the objective of identifying nurses who were victims of psychological harassment, found that individuals who presented high scores in the questionnaire applied did not consider themselves to be victims of psychological harassment, while those with low scores in the questionnaire did consider themselves harassed. According to the study's authors, this result demonstrates how individual differences in personality influence the evaluation of one's own experience of psychological harassment ${ }^{(10)}$. Another study, carried out in Brazil, showed that of nurses who had been identified as victims of psychological harassment according to Leymann's criteria, 20.83\% stated that they did not feel themselves to be victims of psychological harassment(11).

Situations only acquire meaning through the subjectivity of the people involved. What is considered offensive by the victim of harassment, and the effect which the offense has on her, may be disproportionate in relation to what was done. The way each person reacts depends on their personality, allied to their temperament, as well as their history, education and the wounds they received in the past ${ }^{(3)}$. This being so, various scholars have used only the perception of the subject in relation to perceiving themselves as victims or not of psychological harassment. Thus, the objective of the present study was to identify nurses' perceptions in relation to psychological harassment at work, the socioprofessional variables and the characteristics of the psychological harassment involved, and to identify the behaviors of psychological harassment which the nurses had experienced most in the previous twelve months.

\section{Method}

This is an exploratory, cross-sectional study, with a quantitative approach, carried out in a municipality in the north-west region of the state of Paraná, Brazil. It was approved by the Permanent Committee for Research Ethics of the State University of Maringá (Legal opinion 003/2010).

\section{Sample}

In the period between March and April 2010, data was collected on the population of nurses working in the public and private sectors. Regarding the public sector, the nurses worked in two public hospitals, 22 public health centers and five other public services (Municipal Health Board, The Regional Health Board, the Intermunicipal Public Health Trust, the Municipal Penitentiary, and the Fire Service). The nurses working for eight other public health centers did not take part in the research, owing to non-authorization by the units' directors. Regarding the private sector, nurses participated from 11 private hospitals and 20 other private services (health clinics, blood banks, private health insurance companies, residential homes, and emergency services). The process of gathering data resulted in a population of 426 nurses.

The following were considered exclusion criteria: nurses with less than one year of professional experience, nurses who had participated in the pilot test, and nurses who were on holiday or leave at the time of data collection. After applying the exclusion criteria, a sample was obtained of 388 subjects. Through a randomizing procedure 230 nurses were selected to be part of the sample. The parameters used for the calculation of the sample took into account a level of reliability of $95 \%$ and sampling error of $5 \%$. 


\section{Instrument}

The investigation used a specially-constructed socio-professional questionnaire, plus a questionnaire for identifying the behaviors of psychological harassment experienced by the subjects over the previous 12 months, including the behaviors' duration and frequency ${ }^{(12)}$. At the end of the questionnaire, a dichotomous question was added, addressing what the nurse perceived in relation to feeling herself to be a victim of psychological harassment at work.

\section{Procedures}

Before the questionnaire was applied to the sample, a pilot test was undertaken with 27 nurses, belonging to a population of 44 post-graduate students of nursing, with the aim of detecting possible shortcomings in the socio-professional instrument and in the research's layout. Various alterations were suggested by the users, in relation to the layout and to the format of the pages.

The suggestions having been considered, both of the research instruments and the Terms of Free and Informed Consent (TFIC) were converted to an electronic format and hosted on the webpage of the Post-Graduate Nursing program to which the researchers were linked, as the principal form of data collection was via the web.

The nurses were contacted via telephone at their respective institutions to participate in the research. Those who accepted were asked for an email address, and, for those who did not have one, a postal address. For the nurses who did not have email, or who opted for the printed version of the questionnaire, the TFIC, the research's letter of presentation and the questionnaire were sent by post or delivered by hand. A stamped addressed envelope, addressed to the researcher, was also delivered. The nurses were sent an email version of the 'Presentation of the Research', informing them of its aim, and that those selected would have their email addresses recorded in the research setting where they would also find clarifications on how to proceed.

After this stage, there was a simple random selection, and the email addresses of those selected were recorded in the research setting, which automatically created personalized passwords (one for access and a secondary one, to be used if the subject decided to stop participating in the study) and sent them to the email addresses registered, along with a link to the research's address (http://www.pse.uem.br/mobbing/). Those selected were also informed that, should they opt not to participate in the research, all they had to do was email the secondary password to the researcher, who would immediately effect the exclusion of their email address from the electronic register on the system.

After the email addresses of the selected nurses had been registered, the subjects were again contacted by telephone, and were informed about the procedures. A 'Support Manual' was sent by email to those chosen, containing information to be used in the event of difficulty in participating. Once a week, the system automatically sent a reminder email about participating. At the end of a period of twenty days, the e-mails of nurses who had not responded were excluded from the research setting. At this point a new randomized procedure was carried out to substitute the excluded nurses, and so on, until the sample was obtained. Data collection took place between May and September 2010. Due to the nonparticipation of those selected in the period originally proposed, seven further randomized procedures were necessary to select new subjects.

\section{Data analysis}

The data was inserted into the databank of the program Statistical Analysis System (SAS 9.1) and was analyzed by descriptive statistics. Pearson's Chi-square test and the Fisher test were used for the univariate comparisons, and the subject's perception in relation to feeling herself to be a victim or not of psychological harassment at work was considered a response variable.

\section{Results}

22 men (11.06\%) and 177 women (88.94\%) participated in the study, aged between 22 and 58 years old (average of 36 years old, median of 36 and standard deviation of \pm 8.11 years). In relation to type of participation, 175 (87.94\%) used the electronic questionnaire via the web, and $24(12.06 \%)$ used the printed questionnaire. Among the subjects whose email addresses were selected and registered in the research setting, five sent e-mails to the researcher asking for their email addresses to be excluded from the system. However, after handing in the questionnaires, none of the participants regretted participating in the research.

The nurses researched were predominantly female (88.94\%), aged between 31 and 40 years old (35.68\%), with specialist post-graduate qualifications (68.84\%), married $(62.81 \%)$, with children $(63.82 \%)$ and worked in the public sector $(46.73 \%)$. Regarding the other 
variables, the majority held only one job $(73.87 \%) *$, worked the day shift $(68.84 \%)$, had worked in the area for between four and nine years since graduating $(30.15 \%)$ and were paid over 2,500 Brazilian reais per month $(64.32 \%)$, that is, about five minimum salaries, and had worked in their current job for a period of up to three years (34.17\%). There was no statistically significant association between the perception of psychological harassment and the socio-professional variables of sex, age range, level of schooling, marital status, parenthood, work area, number of jobs held simultaneously, shift, years worked since graduating, pay and length of service in current job.

According to the data obtained, 59 (29.65\%) subjects admitted perceiving themselves as victims of psychological harassment at work at the time of the study.

Table 1 - Univariate analysis according to the nurses' perception in relation to feeling that they were victims $(\mathrm{n}=$ 199), according to characteristics of behaviors of psychological harassment. Maringá, Paraná, Brazil, 2010

\begin{tabular}{|c|c|c|c|c|c|}
\hline \multirow{2}{*}{ Variable } & \multirow{2}{*}{ Category } & \multicolumn{2}{|c|}{$\mathbf{N}$} & \multirow{2}{*}{$\%$} & \multirow{2}{*}{$\mathbf{P}$} \\
\hline & & yes & no & & \\
\hline \multirow[t]{4}{*}{ Sex of the aggressor } & Not reported & 3 & 89 & 46.23 & \multirow{4}{*}{$<0.0001^{*}$} \\
\hline & Male & 9 & 6 & 7.54 & \\
\hline & Female & 32 & 30 & 31.15 & \\
\hline & Both & 15 & 15 & 15.07 & \\
\hline \multirow[t]{4}{*}{ Number of aggressors } & Not reported & 4 & 91 & 47.74 & \multirow{4}{*}{$<0.0001^{*}$} \\
\hline & 1 person & 25 & 18 & 21.60 & \\
\hline & 2 to 4 persons & 22 & 28 & 25.12 & \\
\hline & More than 4 persons & 8 & 3 & 5.53 & \\
\hline \multirow[t]{6}{*}{ Frequency of behaviors } & Not reported & 2 & 84 & 43.21 & \multirow{6}{*}{$<0.0001^{*}$} \\
\hline & Rarely & 14 & 35 & 24.62 & \\
\hline & Once a month & 20 & 14 & 17.08 & \\
\hline & Once a week & 13 & 4 & 8.54 & \\
\hline & More than once a week & 6 & 2 & 4.02 & \\
\hline & Every day & 4 & 1 & 2.51 & \\
\hline \multirow[t]{8}{*}{ Period in which faced } & Not reported & 10 & 112 & 61.31 & \multirow{8}{*}{$<0.0001^{\star}$} \\
\hline & 1 to 2 months & 5 & 5 & 5.03 & \\
\hline & 3 to 6 months & 6 & 2 & 4.02 & \\
\hline & 7 to 12 months & 10 & 6 & 8.04 & \\
\hline & 13 to 24 months & 11 & 4 & 7.54 & \\
\hline & 25 to 36 months & 5 & 2 & 3.52 & \\
\hline & 37 to 48 months & 4 & 4 & 4.02 & \\
\hline & $>48$ months & 8 & 5 & 6.53 & \\
\hline \multirow{2}{*}{$\begin{array}{l}\text { Witnessed colleagues being the } \\
\text { victims of psychological harassment }\end{array}$} & Yes & 52 & 77 & 64.82 & \multirow{2}{*}{$<0.0001$} \\
\hline & No & 7 & 63 & 35.17 & \\
\hline
\end{tabular}

* Fisher's Exact Test was used

According to the univariate analysis, the perception of being psychologically harassed is associated with the sex of the aggressor, the number of aggressors, the frequency of the behaviors, the period over which the behavior has been faced, and whether the nurse has witnessed colleagues being victims of psychological harassment (Table 1).
The sum of the behaviors of psychological harassment mentioned by the participating nurses totaled 401 (average of 2.02, median of 1 and standard deviation of 2.67). The average duration of the psychological harassment in the sample studied was 13.45 months, a median of 0.0 and standard deviation of 31.18 .

* Many Brazilian nurses hold two jobs due to low salaries. Translator's Note. 
Table 2 - Distribution of the percentages of the behaviors of psychological harassment most frequently identified by the subjects $(n=199)$. Maringá, Paraná, Brazil, 2010

\begin{tabular}{lc}
\multicolumn{1}{c}{ Behaviors of psychological harassment } & $\%$ \\
\hline They question your decisions & 26.1 \\
You receive verbal attacks criticizing work you have done & 16.6 \\
You receive new tasks, all the time & 15.1 \\
People make jokes about your origin or nationality & 14.1 \\
You are the target of rumors or slander & 13.6 \\
Your aggressor interrupts you continuously when you speak & 13 \\
You are ignored, for example conversation is directed at third parties & 12.1 \\
\hline
\end{tabular}

In Table 2, one may observe that the behaviors "They question your decisions" and "You receive verbal attacks criticizing work you have done" were most frequently mentioned by the subjects.

\section{Discussion}

The results of the present study show that $29.65 \%$ of the nurses perceive themselves to be victims of psychological harassment. This result corroborates that of another study carried out in Portugal $(29.8 \%)^{(13)}$. A study undertaken in Brazil showed that $21.5 \%$ of the nurses felt themselves to be victims of psychological harassment at work(14). An integrative review study demonstrated that recently there has been a considerable advance in publications on the theme, as in the period between 2007 and 2009, the number of publications doubled from previous years ${ }^{(15)}$. The increase in interest among research nurses on related issues and the wide dissemination of these by the media in recent years has contributed to the clarification of workers on this type of violence and, consequently, by greater identification of it by them in the work environment.

Previous studies in Europe have shown a prevalence below that found in the present study, among nurses in Spain $(17.2 \%)^{(10)}$ and hospital nurses in Portugal $(18.5 \%)^{(16)}$. Faced with such discrepant results, it is worth emphasizing that there is still no agreement on the definition of psychological harassment. Some scholars have established the frequency and duration of the behaviors as the parameter for identifying psychological harassment. Others use only the subjects' perception in relation to feeling themselves to be victims, as was the case in this study. Further, there are also the sociocultural characteristics of the professionals from different countries. Thus, it is difficult to compare studies of distinct populations and which used distinct methods.

Among the variables which presented significance, there was a greater frequency of nurses who referred to suffering behaviors of psychological harassment from female individuals, a result which corroborates that found in other studies(16-17). This data may be related to the competition between women in the continuous search for public recognition at work ${ }^{(17)}$. However, it should not be interpreted as related to gender, but rather as a result of the composition of the workforce ${ }^{(1)}$ in nursing, which is predominantly comprised of women.

Another variable which presented statistical significance was the number of aggressors. A higher frequency of nurses (25) reported suffering psychological harassment from "one person", with the "more than four persons" category presenting the lowest number of victims. This data corroborates data from another study, which showed that the victims are attacked by more than four persons only in a quarter of cases ${ }^{(1)}$. A repeated attack from a single aggressor may be a characteristic of psychological harassment and not simply psychological violence in the workplace ${ }^{(17)}$.

Nurses' perception of the harassment increased in line with the frequency of the behaviors. The analysis of the behaviors' frequency becomes an important data, as it allows the organization to distinguish transitory conflicts from those which are intentionally repeated, as well as measuring the frequency with which the conflicts are manifested. (18)

The diagnosis between a false allegation of harassment and a genuine victim is made by the general tone of the complaint. Genuine victims feel doubt and question themselves about their own flaws, and seek solutions to end their torment. Exactly for this reason, they let the situation drag on and do not react early enough, in the attempt to find a solution that allows them to re-establish their dignity. Individuals making false allegations, on the other hand, have no doubts, affirming and making accusations of harassment ${ }^{(3)}$. It may be observed that the group of nurses who referred to having perceived themselves as victims of psychological harassment for less than six months was the one with 
the fewest members compared to the others. Faced with this evidence, one may infer that in the beginning, nurses who are the victims of psychological harassment may not identify or recognize the behaviors of psychological harassment for what they are.

In contrast, it may be seen that more than half of the nurses suffered psychological harassment for over six months. It is important to highlight that a large proportion of the nurses researched worked in the public sector and in both sectors, public and private. A previous study showed that in the public sector psychological harassment can last for years, as the workers are protected against being fired and for this reason the harassment tends to be longer-lasting and more prejudicial to the victim's health(3).

The organizational reality here studied may be known through the perception of those who form part of it ${ }^{(18-19)}$. It may be observed that more than half of the nurses questioned reported witnessing colleagues being the victims of this type of behavior at work. This data concurs with that from a study in Portugal $(42.6 \%)^{(13)}$ and suggests that the practice of this abuse is a common form of behavior in the majority of nursing workplaces.

Among the behaviors of psychological harassment experienced by nurses, the most frequent was "They question your decisions" (26.58\%), followed by "You receive verbal attacks criticizing work you have done" $(16.58 \%)$. Similar results were found in studies undertaken in $\operatorname{Spain}^{(10)}$ and in Portugal(16). Despite the cultural differences in the different countries, one may see that such behaviors have the purpose of discrediting the victim, with the objective of making him or her look incompetent.

Such behaviors are the first visible when the psychological harassment is top-down ${ }^{(3)}$. The stigmatization of the individual through an attack on their reputation and competency may precede the personal attack. In this way it is possible to reduce the victim to a state of impotence and uselessness, being identified as of little importance or use to the institution, and being easily destroyed or punished(20).

Unfortunately it was not possible in this study to identify the behaviors' origins, due to a functional error of the web system during the analysis phase.

\section{Conclusion}

This study's results pinpoint that $29.65 \%$ of the nurses felt that they were victims of psychological harassment at work. Regarding the association of the variables and the subjects' perceptions in relation to psychological harassment at work, it was shown that none of the socio-professional characteristics studied presented associations, although all the variables related to the characterization of psychological harassment presented statistical significance. Based on analysis of this data, one may infer that the work environment and interpersonal relationships were the predominant factors in the determination of the occurrence of the phenomenon, as the factors associated with psychological harassment were predominantly occupational.

In relation to the behaviors of psychological harassment most mentioned by the subjects, "They question your decisions" (26.13\%), followed by "You receive verbal attacks criticizing work you have done" $(16.58 \%)$ both stood out. It may be observed that such behaviors were used to strike at nurses' dignity and make them seem incompetent.

What most calls attention is that the majority of nurses in the sample (64.82\%) had witnessed colleagues being subjected to psychological harassment at work. In this regard, note that this type of violence is a common practice in the organizational environment of nursing or, perhaps, a flawed form of management at work.

Faced with these results, the importance may be understood of opening spaces for discussing workplace violence, such that managers may establish strategic measures for the prevention and containment of this type of violence, so as to ensure health, dignity and wellbeing at work. It also becomes important to discuss the issue in the academic space so as to raise the theme's visibility, so that future nurses may appropriately identify and confront this type of violence.

\section{References}

1. Leymann $\mathrm{H}$. The content and development of mobbing at work. Eur.J Work Organiz Psychol. 1996;5(2):165-84. 2. Piñuel Zabala I, Oñate Cantero A. La incidencia del Mobbing o acoso psicológico en el trabajo en España. Lan Harremanak. 2002;7(2):35-62.

3. Hirigoyen MF. Mal-estar no trabalho: redefinindo o assédio moral. 4. ed. Rio de Janeiro: Bertrand Brasil; 2009. 350 p.

4. Palácios $M$, Rego S. Bullying: another invisible epidemic? Rev Bras Educ Med. 2006;30(1):3-5.

5. Pedroso VG, Gonçalves V, Limongi AC, Martins F de AS, Hrdlicka $\mathrm{H}$, Jorge SM, et al. Aspectos conceituais de assédio moral: um estudo exploratório. Rev Adm Saúde. 2006;8(33):139-47. 
6. Cezar-Vaz MR, Soares JFS, Figueiredo PP, Azambuja EP, Sant'anna CF, Costa VZ. Percepção do risco no trabalho em saúde da família: estudo com trabalhadores no sul do Brasil. Rev. Latino-Am. Enfermagem. [periódico na Internet]. nov-dez 2009 [acesso 23 set 2011]; 17(6):761-7. Disponível em: http://www.scielo.br/pdf/ rlae/v17n6/pt_06.pdf

7. Dalmolin GL, Lunardi VL, Lunardi WD Filho. O sofrimento moral dos profissionais de enfermagem no exercício da profissão. Rev Enferm UERJ. 2009;17(1):35-40.

8. Yildirim D. Bullying among nurses and its effects. Int Nurs Rev. 2009;56(1):504-11.

9. Sá L, Fleming MF. Bullying, burnout, and mental health amongst portugueses nurses. Issues Ment Health Nurs. 2008;29(4):411-26.

10. Fornés-Vives J, Martinez-Abascal MA, García-Banda Garcia G. Variables socioprofesionales implicadas en el hostigamiento psicológico en enfermería. Enferm Clín. 2008;18(3):127-33.

11. Fontes KB. Do invisível ao invisível: assédio moral e o trabalho do enfermeiro. Dissertação [Mestrado em Enfermagem]. Maringá (PR): Universidade Estadual de Maringá; 2011. 109 p.

12. Leymann $H$, Tallgren $U$. Undersokning av frekvensen vuxenmobbning inom SSAB (Investigation into the frequency of adult mobbing in SSAB a Swedish steel company using the LIPT questionnaire). Arbete, Manniska, Miljo. 1989;(1):110-5.

13. Carvalho GD. Mobbing: assédio moral em contexto de enfermagem. Rev Invest Enferm [periódico na Internet]. 2010 Fev. [acesso 20 abril 2012]; 21(1):28-42. Disponível em: http://www.sinaisvitais.pt/index.php?option=com content\&view $=$ article\&id $=468$ : revista-investigacaoenfermagem-no21\&catid $=31$ \&Itemid $=34$

14. Xavier ACH, Barcelos CRV, Lopes JP, Chamarelli PG, Ribeiro SS, Lacerda LS, et al. Workplace moral harassment in Rio de Janeiro health sector: some characteristics. Rev Bras Saúde Ocup. 2008;33(117):15-22.

15. Fontes KB, Pelloso SM, Carvalho MDB. Tendency of the studies on moral harassment and nursing staff. Rev Gaucha Enferm. 2011;32(4):815-22.

16. João AL. Mobbing, relações interpessoais e satisfação laboral. Int J Develop Psychol. 2010 [acesso 20 julho 2011]; 1(1):399-406. Disponível em: http:// www.forumenfermagem.org/index.php?option $=\mathrm{com}_{-}$ content\&view $=$ article\&id $=3567$ : mobbing -relacoesinterpessoais-e-satisfacao-laboral\&catid=216: julho-aagosto-2010
17. Barbosa R, Labronici LM, Sarquis LMM, Mantovani MF. Violência psicológica na prática profissional da enfermeira. Rev Esc Enferm USP. 2011;45(1):26-32.

18. Martins MCF, Ferraz AMS. Propriedades psicométricas das escalas de assédio moral no trabalho: percepção e impacto. Psico - UFS. 2011;16(2):163-73.

19. Castellón AMD. Violência laboral em enfermeiras: explicações e estratégias de enfrentamento. Rev. LatinoAm. Enfermagem. [Internet]. jan-fev 2011 [acesso 26 jun 2012];19(1):[08 telas]. Disponível em: <http:// www.scielo.br/pdf/rlae/v19n1/pt_2 1.pdf>

20. Hutchinson M, Wilkes L, Vickers M, Jackson D. The development and validation of a bullying inventory for the nursing workplace. Nurs Res. 2008;15(2):19-30. 